\title{
Rapid assessment of fruit-color selection by birds using artificial fruits at local scale in Central Amazonia
}

\author{
Rafael ARRUDA ${ }^{1, *}$, Domingos J. RODRIGUES ${ }^{1,2}$, Thiago J. IZZO'
}

\section{ABSTRACT}

Modeling clays have been used in several ecological experiments and have proved to be an important tool to variables control. The objective of our study was to determine if fruit color in isolated and grouped displays influences the fruit selection by birds in the field using artificial fruits. Data were collected in six plots distributed homogeneously in $3 \mathrm{~km}$ long trails with a minimum distance of $0.5 \mathrm{~km}$. We used a paired experimental design to establish our experiments, so that all treatments were available to the local bird community in each plot. Overall, red was more pecked than brown and white. Isolated red and brown displays were significantly more pecked than others display. Even though our study was conducted in small spatial scales, artificial fruits appeared to be efficient in register fruit consumption attempts by bird. Although inconclusive about selective forces that sharp the dynamics of fruit color polymorphisms and choice by frugivorous birds, our findings corroborate recent studies wherein birds showed preferences by high- over low-contrast fruit signals.

KEYWORDS: Fruit color, Paired experimental design, Background foliage coloration, Contrast hypothesis.

\section{Utilização de frutos artificiais para avaliar seleção de cores por aves em escala local na Amazônia Central}

\begin{abstract}
RESUMO
Atualmente o uso de massa de modelar tem sido amplamente utilizado para testar várias hipóteses ecológicas. O objetivo deste trabalho foi determinar se cores de frutos artificiais dispostos isoladamente nos ramos, ou em agregação, influenciaram a escolha das aves. Coletamos os dados em seis parcelas distribuídas homogeneamente em uma trilha de 3 km. Nós usamos desenho experimental pareado, de modo que todos os tratamentos estavam disponíveis para a comunidade local de aves em cada parcela. Os frutos artificiais vermelhos foram mais bicados do que marrons e brancos. Separando-se nos dois diferentes arranjos, vermelhos e marrons isolados foram significativamente mais bicados de que os outros arranjos. Embora nosso estudo tenha sido realizado em pequena escala espacial, frutos artificiais foram eficientes em registrar tentativas de consumo pelas aves. Embora não conclusivo a respeito da pressão seletiva que molda a dinâmica de polimorfismos nas cores dos frutos, bem como dos padrôes de escolha pelos frugívoros, nosso trabalho corrobora recentes estudos onde aves preferiram frutos com maior contraste em relação à coloração de fundo imposta pela vegetação.
\end{abstract}

PALAVRAS-CHAVE: Cor do fruto, Desenho experimental pareado, Coloração de fundo, Hipótese de contraste.

\footnotetext{
1 Coordenação de Pesquisas em Ecologia, Instituto Nacional de Pesquisas da Amazônia, Av. André Araújo, 2936 - Aleixo. CEP 69011-970. Manaus, AM, Brazil. *Author for correspondence: e-mail: rsarruda@yahoo.com.br

2 Instituto Universitário do Norte Matogrossense, Universidade Federal de Mato Grosso, CEP 78550-000, SINOP, MT, Brazil.
} 


\section{INTRODUCTION}

Determination of the traits governing fruit selection by birds is important to understand and determine coevolutionary processes of fruiting plants and their dispersers, mainly which birds are the primary seed dispersers for many plant species in various habitats (Howe \& Smallwood, 1982). There are several traits that may influence birds' fruit selection, such as fruit color, size, physical accessibility, crop size, habitat and distance between fruiting plants (Moore \& Willson, 1982; Moermond \& Denslow, 1983; Levey et al., 1984; Denslow, 1987; Sallabanks, 1993; Galetti et al., 2003). However, determining the importance of such traits independently is a major challenge in these studies because fruit traits are often correlated (Gervais et al., 1999; Alves-Costa \& Lopes, 2001).

The use of artificial fruits is a way to manipulate fruit traits independently (Alves-Costa \& Lopes, 2001). Studies evaluating fruit-color selection by birds are usually conducted with captive birds which might be influence the birds' choice (e.g. Willson et al., 1990; Willson \& Comet, 1993; Puckey et al., 1996; Giles \& Lill, 1999). An alternative in this case is the use of artificial fruits in field experiments. Modeling clays have been used in several ecological experiments and have proved to be an important tool to control variables (VasconcellosNeto et al., 2000; Galetti et al., 2003; Kuchta, 2005; Koh \& Menge, 2006). Alves-Costa \& Lopes (2001) tested the use of artificial fruits in the field for registering fruit consumption attempts by birds and discuss the advantages and limitations of this technique.

Because birds have an excellent visual acuity and welldeveloped color vision (Goldsmith, 1990), they probably use color to find and recognize fruits (Wheelwright \& Janson, 1985). Recently Alves-Costa \& Lopes (2001) and Galetti et al. (2003) demonstrated that artificial clay fruits do not interfere in acceptance by birds in field experiments. The main objective of our study was to determine if fruits of different colors in isolated and grouped displays influence fruit selection by birds in the field. We expected that fruit aggregation is more important to fruit localization and selection by birds. The aggregated display may be more easily found by frugivores, and may be attractive to more individuals and species of birds (Denslow, 1987).

\section{MATERIAL AND METHODS}

\section{STUDY AREA}

Field work was conducted in terra firme tropical rain forest at $\mathrm{Km} 81$ of the BR 319 (Manaus-Porto Velho highway), between Purus and Madeira rivers (03.60665 S; 060.19784º $\mathrm{W})$. Mean annual rainfall in the study area is around 2300 $\mathrm{mm}$, with a distinct wet season during November-May, and a dry season between August-September (Brasil, 1978). Climate is equatorial hot and moist, and soil types are red-yellowish podsol (Brasil, 1978). The mainly vegetation type is closed tropical forest (Brasil, 1978).

\section{EXPERIMENTAL DESIGN}

Data were collected in six plots distributed homogeneously in $3 \mathrm{~km}$ long trails with a minimum distance of $0.5 \mathrm{~km}$. Plots were $250-\mathrm{m}$ long and positioned to follow the topographic isoclines (Magnusson et al., 2005). To address our objectives, we used a similar methodology of Alves-Costa \& Lopes (2001). We molded 540 artificial fruits with $14 \mathrm{~mm}$ diameter spherical in three different colors, red, brown and white (180 fruits in each color). We used modeling clay containing no petroleum derivatives, nontoxic and odorless. Each fruit was tied on the branch by a cord that had a knot at the end. About $12 \mathrm{~cm}$ of cord was kept outside the fruit for attaching to the branches.

We use a paired experimental design to establish our experiments, so that all treatments were available to the local bird community in each plot. In each plot, six shrubs randomly received 15 fruits of one color (display station), arranged in the understory shrubs (1-2 m). We made two treatments for each color - isolated and grouped fruits. For the isolated treatment, the artificial fruits were placed in different branches of the shrub (Red isolated [Ri], Brown isolated [Bi], and White isolated [Wi]). For the grouped treatment, the artificial fruits were grouped in only one branch of the shrub, aggregated display (Red aggregated [Ra], Brown aggregated $[\mathrm{Ba}]$, and White aggregated [Wa]). Only plants without fruits and/or flowers were used. Moreover, leaves were removed from the point of fruit attachment, making the fruits easily visible (cf. Alves-Costa \& Lopes 2001). In addition, all understory shrubs and trees were checked for available fruits. However, because fruit availability was extremely low during the study period (just one indeterminate palm with orange fruits), we did not use this information in the statistical model and assume that the experiment was conducted in a low food availability season.

Plants were checked every day for a period of six days (11 to 17 May 2005) during the wet season. We counted the number of pecked or fallen fruits. Pecked fruits were remodeled and fallen fruits were replaced. We did not consider removed fruits, because several fruits fell due a strong rain during the experiments and the high humidity in the understory. Based on some traits of bill marks, we recorded five different categories of pecked fruits, following Alves-Costa $\&$ Lopes (2001).

Because the lack of data normality, we used Wilcoxon signed-rank test (Zar, 1999) to assess the hypothesis that are 
differences in number of fruits pecked in three different colors in isolated and grouped displays.

\section{RESULTS}

Two hundred and sixty-three artificial fruits were pecked $(48.7 \%)$ and seven were bitten $(1.3 \%)$. Red was the most pecked artificial fruit (62.2\%), followed by brown $(57.2 \%)$ and white $(26.7 \%)$. We observed five types of different impressions in the artificial fruits (Table 1). Since we were only interested in birds attracted to fruits, we placed bitten fruits in a single category (tooth mark impressions on opposite sides), as it is the less common damage category in our surveys (Table 1). Thus, peck marks by birds were categorized in four groups: numerous thin pecks on fruit's middle; pecks forming shallow or deep furrows; small and shallow pecks characterized by two closed holes; large and deep holes (Table 1). Fallen fruits totalized 658 which 231 were red, 226 were brown, and 201 were white.

In the display stations, 83 red isolated artificial fruits were pecked $(92.2 \%)$, followed by 70 brown isolated fruits $(77.8 \%)$, 38 brown aggregated fruits (42.2\%), 30 red aggregated fruits $(33.3 \%)$, and finally by 27 white isolated fruits $(30.0 \%)$ and 21 white aggregated fruits $(23.3 \%)$. There was no difference between red and brown isolated displays and both were significantly more pecked than the other displays (Figure 1). In addition, there was no difference in the number of peaked fruits between red, brown and white aggregated and white isolated displays (Figure 1).

\section{DISCUSSION}

Birds peak preferentially isolated red and brown fruit models rather than white fruits. Brown is considered a dark color (like black, blue and green), and inherently less conspicuous to dispersers than bright bird fruits, as red and white (like orange and yellow) (Wheelwright \& Janson, 1985). Red accounted $36 \%$ of the bird-dispersed plant species in Neotropical sites of Peru and Costa Rica (Wheelwright \& Janson, 1985). Moreover, these authors found that brown were

Table 1 - Number of bite and peck marks on the artificial fruits in six different categories (cf. Alves-Costa \& Lopes, 2001). Category (a) Tooth mark impressions on opposite sides; (b) Numerous thin pecks on fruit's middle; (c) Pecks forming shallow or deep furrows; (d) Small and shallow pecks characterized by two closed holes; (e) Large and deep perforations.

\begin{tabular}{lcccccc}
\hline \multirow{2}{*}{ Fruit-color } & \multicolumn{6}{c}{ Categories } \\
\cline { 2 - 7 } & $\mathrm{a}$ & $\mathrm{b}$ & $\mathrm{c}$ & $\mathrm{d}$ & $\mathrm{e}$ & Total \\
\hline Red & 6 & 13 & 42 & 54 & 27 & 142 \\
Brown & 1 & 15 & 31 & 53 & 37 & 137 \\
White & 0 & 4 & 12 & 22 & 11 & 49 \\
Total & 7 & 32 & 85 & 129 & 75 & 328 \\
\hline
\end{tabular}

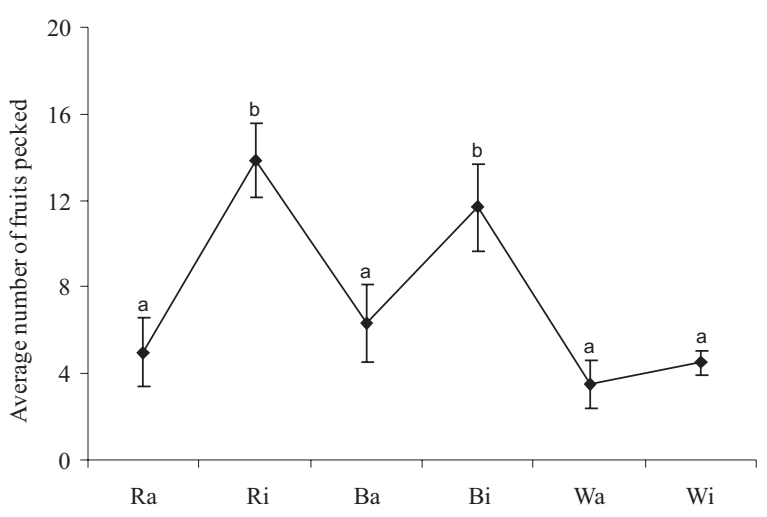

Figure 1 - Number of pecked fruits in each display station. Bars represent standard error. Abbreviations: Ra - Red aggregated, Ri - Red isolated, Ba Brown aggregated, Bi - Brown isolated, Wa - White aggregated, and Wi - White isolated. Different letters indicate significant differences (Wilcoxon signed ranked test, $p<0.05$ )

the less common color $(0.7 \%$ in Peru, $3.9 \%$ in Costa Rica) than white (18.7\% in Peru, 9.5\% in Costa Rica). Studies that evaluate bird preferences for fruit colors with captive birds showed that birds tended to prefer red fruits (McPherson, 1988; Willson et al., 1990). Avian preferences by red fruits were also observed in field experiments (Gervais et al., 1999; Alves-Costa \& Lopes, 2001). As birds discriminate between fruit colors, our results suggests that the perception of color by birds was not influenced by use of artificial fruits (see also Alves-Costa \& Lopes, 2001).

Burns \& Dalen (2002) and Schmidt et al. (2004) found strong support for the prediction that background foliage coloration influences fruit color preferences by avian frugivores. These authors demonstrated that red fruits had higher removal rates because displayed against contrasting background foliage. The contrast hypothesis predicts that diurnal seed dispersers select fruit colours mainly based on their conspicuousness rather than their color, i.e., greater contrasts of fruits increase the probability of detection by dispersers. The higher rates of peaks on red and brown fruit models in this study seem to corroborate this hypothesis. Even though brown colour can be considered as inconspicuous, it is a union of yellow and red colours. Therefore, both red and brown fruits may present similar wavelength, which, in turn, influence the colour perception of birds. Thus, brown probably exhibit the same signals of conspicuousness presented of red colour against strong green background foliage of Amazonian understory.

Fruit color displays roles are to prevent or to attract consumers. Thus, the presentation of fruits, associated with color display, may influence the selective pressure by frugivorous birds in its foraging behavior. Aggregated plants or plants with clustered fruits are probably more noticeable 
at a distance than solitary plants or plants with isolated fruits (Wheelwright \& Janson, 1985). In contrast to Denslow (1987) who did not find significant differences in fruit removal between aggregated and isolated bushes of Sambucus pubens, we found significant higher fruits damaged by birds in isolated than aggregated displays. Some hypotheses can explain this pattern. Firstly, birds perceived that fruits in aggregated display were inedible after first or few contacts. Alves-Costa \& Lopes (2001) observed a slight decrease in the rate of consumption of artificial fruits after $15^{\text {th }}$ day of the experiment, which indicate that birds were beginning to avoid the artificial fruits. In this case, birds of the local community "learned" that the model fruits were unpalatable (Alves-Costa \& Lopes 2001). In our study, individuals of the local community could be recognized and avoided places where fruit models were available and could have stopped foraging, or decrease the foraging for fruits on these patches. Secondly, Amazonian forest understory is highly complex and closed. Thus, a single available fruit was just found in a median-short distance. Within a landscape perspective, more distributed resources in the environment can be more easily seen by birds than a small and rich path of resources. However, in large scale, it does not means that the consumption rate necessarily is unequal because once that where these rich path is found, all the resource could be used.

We recorded four categories of marks made by birds on artificial fruits. Alves-Costa \& Lopes (2001) observed no more than one pecking pattern on a single fruit. However, we registered that several fruits have more than one peak mark, but do not necessarily reflects differences in diversity of understory birds in both areas. Moreover, we observed marks of different categories in the same artificial fruit. These authors suggested that different bird species may assigned to the same categories, but same bird species did not generated marks in more than one category. Few categories suggest that fruit consumption in the understory is made by a few frugivores bird species (Alves-Costa \& Lopes 2001), mainly because insectivorous birds are predominantly in the understory of Amazonian forest (see Bierregaard \& Lovejoy, 1989; Bierregaard, 1990).

Frugivores have been recognized as the most likely agents of selection on fruit color (Willson \& Whelan, 1990). Although frugivore preferences among colored fruits are found in laboratory tests (Willson \& Comet, 1993; Puckey et al., 1996; Giles \& Lill, 1999), color preferences are infrequently found in field studies under natural conditions (Willson \& O’Down, 1989; Traveset \& Willson, 1998; Traveset et al., 2001). Whitney \& Stanton (2004) studying Acacia ligulata in Australia suggested that pleiotropic effects may be a common feature on fruit color polymorphism, and that frugivores may not always be the most important. These authors presented the first evidence that fruit color polymorphism might be maintained by heteropteran insects seed predator (Whitney $\&$ Stanton, 2004). Thus, roles of frugivores in the dynamics of fruit color polymorphisms remain uncertain. Even though our study was conducted in small spatial scales in the Amazon, artificial fruits were efficient in register fruit consumption attempts by bird. Although inconclusive about selective forces that sharp the dynamics of fruit color polymorphisms and choice by frugivorous birds, our findings corroborated recent studies wherein birds showed preferences by high- over low-contrast fruit signals (e.g. Burns \& Dalen, 2002; Schmidt et al., 2004).

\section{ACKNOWLEDGMENTS}

We are very grateful to Marina Anciães and Antônio Weber for critical reading of early drafts, Albertina P. Lima and Flávia R.C. Costa for advice during fieldwork. Financial support was provided by CAPES and FAPEAM (Proc. 542/2004). This work was supported by graduate fellowships from Coordenação de Aperfeiçoamento de Pessoal em Nível Superior (CAPES) to R. Arruda and T.J. Izzo and Conselho Nacional de Desenvolvimento Científico e Tecnológico (CNPq) to D.J. Rodrigues. This research was conducted as part of a tropical ecology field course provided by the Ecology Graduate Program of the Instituto Nacional de Pesquisas da Amazônia.

\section{LITERATURE CITED}

Alves-Costa, C.P.; Lopes, A.V. 2001. Using artificial fruits to evaluate fruit selection by birds in the field. Biotropica, 33: 713-717.

Bierregaard Jr., R.O. 1990. Species composition and trophic organization of the understory bird community in a Central Amazonian terra firme forest. In: Gentry, A. (Ed). Four Neotropical Rainforests. New Haven: Yale Univ. Press. p 217-236

Bierregaard Jr., R.O.; Lovejoy, T.E. 1989. Effects of forest fragmentation on Amazonian understorey bird communities. Acta Amazonica, 19: 215-241.

Projeto RADAMBRASIL. 1978. Folha SB.20 Purus; geologia, geomorfologia, pedologia, vegetação e uso potencial da terra. (ed Mineral, D.N.P.), vol. 17.

Burns, K.C.; Dalen, J.L. 2002. Foliage color contrasts and adaptive fruit color variation in a bird-dispersed plant community. Oikos, 96: 463-469.

Denslow, J.S. 1987. Fruit removal rates from aggregated and isolated bushes of the red elderberry, Sambucus pubens. Canadian Journal of Botany, 65: 1229-1235.

Galetti, M.; Alves-Costa, C.P.; Cazetta, E. 2003. Effects of forest fragmentation, anthropogenic edges and fruit colour on the consumption of ornithocoric fruits. Biological Conservation, 111: 269-273. 
Gervais, J.A.; Noon, B.R.; Willson, M.F. 1999. Avian selection of the color-dimorphic fruits of salmonberry, Rubus spectabilis: a field experiment. Oikos, 84: 77-86.

Giles, S.; Lill, A. 1999. The effect of fruit abundance, conspicuosness and sugar concentration on fruit colour choice by captive silvereyes. Ethology Ecology and Evolution, 11: 229-242.

Goldsmith, T.H. 1990. Optimization, constraint, and history in the evolution of eyes. Quarterly Review of Biology, 65: 281-322.

Howe, H.F.; Smallwood, J. 1982. Ecology of seed dispersal. Annual Review of Ecology and Systematics, 13: 201-228.

Koh, L.P.; Menge, D.N.L. 2006. Rapid assessment of lepidoptera predation rates in Neotropical forest fragments. Biotropica, 38: 132-134.

Kuchta, S.R. 2005. Experimental support for aposematic coloration in the salamander Ensatina eschscholtzii xanthoptica: Implications for mimicry of Pacific Newts. Copeia, 2005: 265-271.

Levey, D.J.; Moermond, T.C.; Denslow, J.S. 1984. Fruit choice in Neotropical birds: the effect of distance between fruits on preference patterns. Ecology, 65: 844-850.

Magnusson, W.E.; Lima, A.P.; Luizão, R.C.; Luizão, F.; Costa, F.R.C.; Castilho, C.V.; Kinupp, V.F. 2005. RAPELD: a modification of the Gentry method for biodiversity surveys in long-term ecological research sites. Biota Neotropica, 5: <http://www.biotaneotropica.org.br/v5n2/pt/abstract?pointof-view+bn01005022005>.

McPherson, J.M. 1988. Preferences of cedar waxwings in the laboratory for fruit species, colour and size: a comparison with field observations. Animal Behavior, 36: 961-969.

Moermond, T.C.; Denslow, J.S. 1983. Fruit choice in Neotropical birds: effects of fruit type and accessibility on selectivity. Journal of Animal Ecology, 52: 407-420.

Moore, L.A.; Willson, M.F. 1982. The effect of microhabitat, spatial distribution, and display size on dispersal of Lindera benzoin by avian frugivores. Canadian Journal of Botany, 60: 557-560.

Puckey, H.L.; Lill, A.; O’Dowd, D.J. 1996. Fruit color choices of captive silvereyes (Zosterops lateralis). Condor, 98: 780-790.

Sallabanks, R. 1993. Hierarchical mechanisms of fruit selection by an avian frugivore. Ecology, 74: 1326-1336.
Schmidt, V.; Schaefer, H.M.; Winkler, H. 2004. Conspicuousness, not colour as foraging cue in plant-animal signalling. Oikos, 106: 551-557.

Traveset, A.; Riera, N.; Mas, R.E. 2001. Ecology of fruit-color polymorphism in Myrtus communis and differential effects of birds and mammals on seed germination and seedling growth. Journal of Ecology, 89: 749-760.

Traveset, A.; Willson, M.F. 1998. Ecology of the fruit-color polymorphism in Rubus spectabilis. Evolutionary Ecology, 12: 331-345.

Vasconcellos-Neto, J.; Souza, A.L.T.; Guimarães, M.M.; Faria, D.M. 2000. Effects of color, shape and location on detection of cactus fruits by a lizard. Journal of Herpetology, 34: 306-309.

Wheelwright, N.T.; Janson, C.H. 1985. Color of fruit displays of bird-dispersed plants in two tropical forests. American Naturalist, 126: 777-799.

Whitney, K.D.; Stanton, M.L. 2004. Insect seed predators as novel agents of selection on fruit color. Ecology, 85: 2153-2160.

Willson, M.F.; Comet, T.A. 1993. Food choices by northwestern crows: experiments with captive, free-ranging and hand-raised birds. Condor, 95: 596-615.

Willson, M.F.; Graft, D.A.; Whelan, C.J. 1990. Color preferences of frugivorous birds in relation to the colors of fleshy fruits. Condor, 92: 545-555.

Willson, M.F.; O’Dowd, D.J. 1989. Fruit color polymorphism in a bird-dispersed shrub (Rhagodia parabolica) in Australia. Evolutionary Ecology, 3: 40-50.

Willson, M.F.; Whelan, C.J. 1990. The evolution of fruit color in fleshy-fruited plants. American Naturalist, 136: 790-809.

Zar, J.H. 1999. Biostatistical analysis. Fourth edition, Prentice Hall, New Jersey. 663pp.

Recebido em 29/01/2007

Aceito em 17/01/2008 
